\title{
Serum soluble interleukin 2 receptor in systemic lupus erythematosus: effects of disease activity and infection
}

\author{
K L Wong, R P O Wong
}

\begin{abstract}
Serum soluble interleukin 2 receptor (sIL2R) was measured in patients with active and inactive systemic lupus erythematosus (SLE). The concentration of sIL2R was higher in inactive SLE than in normal controls and was significantly increased in active compared with inactive SLE. When patients with active SLE were followed up serially it was found that the sIL2R concentration fell when the disease became inactive. There was no statistically significant association between sIL2R and the grades of disease activity, however.

In patients with either active or inactive SLE and infection the sIL.2R concentration was much higher than in those without infection. Chronic infection (tuberculosis or candida) was associated with a much higher concentration of sIL2R than pyogenic or herpes zoster infection. The sIL $2 R$ concentration helps to distinguish infection in patients with SLE.
\end{abstract}

Systemic lupus erythematosus (SLE) is the prototype of autoimmune disease arising from defective immunoregulation. ${ }^{1}$ Various immunopathogenetic mechanisms have been described and a wide array of observable defects proposed, debated, and rebutted. ${ }^{2-5}$

Soluble interleukin 2 receptor (sIL2R) is a molecule derived from the membrane interleukin 2 receptor. $^{67}$ It is easily measurable in serum and body fluids by enzyme linked immunosorbent assay (ELISA) ${ }^{6}$ and has been reported to be increased in SLE ${ }^{8-10}$ rheumatoid arthritis, ${ }^{811}$ infection, ${ }^{12}$ and lymphoma. ${ }^{13} 14$

We investigated the usefulness of sIL2R in defining activity and major organ involvement in SLE, and, particularly, whether sIL2R can distinguish SLE disease activity from infection.

\section{Patients and methods}

PATIENTS

Eighty eight patients, who satisfied the revised criteria for the diagnosis of SLE, ${ }^{15}$ were studied prospectively. Serum samples were collected during active and inactive phases of the disease and stored at $-20^{\circ} \mathrm{C}$. Disease activity was

Department of Medicine, Queen Mary Hospital, University of Hong Kong, Hong Kong K L Wong R P O Wong Correspondence to: Dr K L Wong. Accepted for publication 14 August 1990
C4, serum creatinine, urinary protein, haemoglobin, platelet count) and given a score as follows: $0=$ absence of symptoms, signs, or normal laboratory values; $1=$ moderate and 2 =severe symptoms, signs, or laboratory abnormalities. Disease activity was classified as in remission, mild, moderate, and severe when the score was $0,1-10,11-20$, and $>20$ respectively. Controls, aged 12-55, were selected from hospital patients and had no evidence of infection or inflammation. They comprised 14 patients with congenital heart disease without evidence of infective carditis for at least six months, six patients with minimal diazepam overdose, and three patients with non-peptic ulcer dyspepsia.

Serum samples were also collected from the cohort of patients who developed major infections during the period of follow up. Their disease status was assessed and classified as inactive or active using the above system.

\section{DETECTION OF SIL2R}

Serum sIL2R was determined using a sandwiched ELISA (Cell-free, T Cell Science Inc, Cambridge, Massachusetts). ${ }^{6}$ Briefly, polystyrene microtitre wells were coated with $100 \mu \mathrm{l}$ anti-Tac equivalent monoclonal antibody. Serum or sIL2R standards were added to these wells. A horseradish peroxidase-conjugated anti-IL2R monoclonal antibody directed against a second epitope on the interleukin 2 receptor molecule was added, followed by addition of the substrate. The reaction was stopped after 30 minutes and absorbance determined at $490 \mathrm{~nm}$. A standard curve was prepared from the sIL2R standard and the values of the sample were read off this standard curve. If the absorbance exceeded the standard curve, a 1:5 dilution of the sample was made and retested. This result was read and multiplied by the dilution factor.

ANALYSIS OF DATA

Statistical analysis was by Student's $t$ test or one way variance as appropriate.

\section{Results}

Fifty patients with active SLE (eight male, 42 female; mean (SD) age $29 \cdot 3(10 \cdot 2)$ years) and 50 patients with inactive SLE (four male, 46 female; age $29.9(8.2)$ years) were recruited into the prospective study. Serum samples from 27 of these patients were taken both at active and inactive phases. Sixteen patients with active SLE and eight patients with inactive SLE neurological events, malaise not due to any other cause, fundoscopic abnormalities, lymphadenopathy, splenomegaly) and by laboratory findings (anti-DNA antibody, C3, al. ${ }^{16}$ In brief, the activity of the disease was assessed by symptoms and signs (alopecia, rash, 
Table 1 Infections developed by patients with systemic lupus erythematosus (SLE)

\begin{tabular}{lcl}
\hline Infection & $\begin{array}{l}\text { Active } \\
\text { SLE }\end{array}$ & $\begin{array}{l}\text { Inactive } \\
\text { SLE }\end{array}$ \\
\hline Tuberculosis & 7 & 3 \\
Candidiasis & 0 & 1 \\
Penicilliosis & 1 & 0 \\
Streptococcal pneumonia & 1 & 0 \\
Pseudomonas aeruginosa infection & 1 & 0 \\
Herpes zoster & 1 & 2 \\
Mycoplasmal pneumonia & 0 & 1 \\
Mixed pyogenic infection & 2 & 0 \\
Others & 3 & 0 \\
Total & 16 & 8 \\
\hline
\end{tabular}

developed major infections during this period. Table 1 lists the types of infection.

SERUM SIL2R IN PATIENTS WITH SLE ACCORDING TO DISEASE ACTIVITY

The mean (SEM) concentration of SIL2R in inactive SLE was higher than that in the controls (377.90 (165.65) v 241.83 (50.42) $\mathrm{U} / \mathrm{ml} ; \mathrm{p}<0.05$ ) (fig 1 ). The concentration of sIL2R in active SLE was higher than that in inactive SLE (769.59 (526.99) $v 377.90$ (165.65) $\mathrm{U} / \mathrm{ml} ; \mathrm{p}<0.000)$. In those patients who were followed up serially the sIL2R fell as the disease was controlled (772.18 (561.95) $v \quad 388 \cdot 16$ (158.27) $\mathrm{U} / \mathrm{ml} ; \mathrm{p}=0.002$ ) (fig 2). When the group of patients with active SLE was subdivided according to the severity of disease activity there were no statistical differences in the concentrations of sIL2R according to mild, moderate, or severe disease activity (table 2). All these 'active' subgroups, however, showed significantly higher mean sIL2R concentrations than inactive SLE.

\section{SERUM SIL2R IN PATIENTS WITH SLE}

AND INFECTION

During infection sIL2R concentrations were generally much higher so that differences between active and inactive SLE were no longer apparent (fig 1). In active SLE the mean concentration of sIL2R was significantly higher in those with infection than in those without

Figure 1 Serum soluble interleukin 2 receptor (sIL2R) in patients with systemic lupus erythematosus $(S L E)($ mean $(S E M))$.

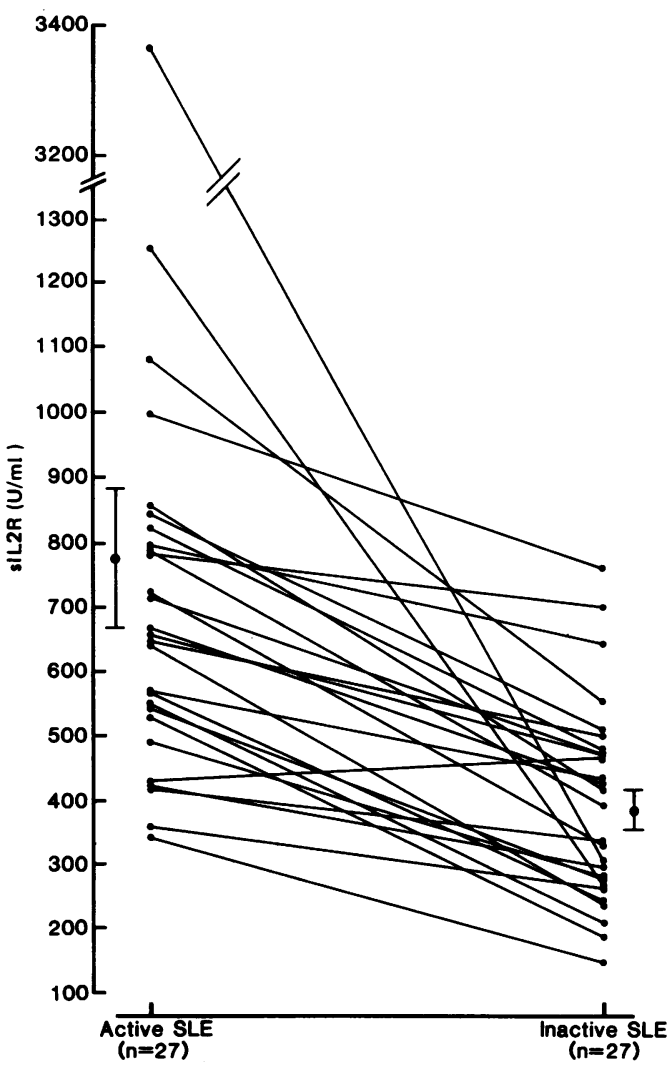

Figure 2 Serial serum soluble interleukin 2 receptor (sIL2R) in patients with systemic lupus erythematosus $(S L E)($ mean $(S E M))$.

Table 2 Concentrations of serum soluble interleukin 2 receptor (sIL2R) according to disease activity. Values are given as mean (SEM)

\begin{tabular}{lll}
\hline Disease activity & $\begin{array}{l}\text { Number of } \\
\text { patients }\end{array}$ & $\begin{array}{l}\text { Serum } s I L 2 R \\
(U / m l)^{*}\end{array}$ \\
\hline Inactive & 50 & $377 \cdot 90(165 \cdot 65)$ \\
Mild & 7 & $627.87(258.13)$ \\
Moderate & 31 & $713.41(434.36)$ \\
Severe & 12 & $997 \cdot 40(779 \cdot 69)$ \\
\hline
\end{tabular}

"Inactive $v$ mild, moderate, or severe: $p=0.004,0.000,0.000$. Mild $v$ moderate or severe: $p=0.662,0.126$.

Moderate $v$ severe: $\mathrm{p}=0 \cdot 081$.

$(2265 \cdot 41(2275 \cdot 81) \quad v 769.59(526.99) \mathrm{U} / \mathrm{ml}$; $\mathrm{p}<0.000)$. Similar results were found in inactive SLE with or without infection (2063.60 (1569.61) v 377.90 (165.65); $\mathrm{p}<0.000)$. Among the infections, chronic infection with tuberculosis or candida gave much higher concentrations of sIL2R than pyogenic or herpes zoster infection (3410.17 (2294.94) v 980.05 (422.27); $\mathrm{p}<0.000)$. In the group with SLE and infection the sIL2R concentration was higher in those with inactive SLE $(p=0.022)$.

INDIVIDUAL SIL2R CONCENTRATIONS

When individual concentrations of sIL2R were considered it was seen that all normal controls, $41 / 50(82 \%)$ patients with inactive SLE, and $12 / 50(24 \%)$ with active SLE had concentrations less than 500 units $/ \mathrm{ml}$. At the other extreme, $13 / 15$ patients with sIL2R $\geqslant 1501$ units $/ \mathrm{ml}$ had SLE associated with infection. Thus when the sIL2R concentration is above 1500 units $/ \mathrm{ml}$ the probability of infection is high $\left(\chi^{2}=49.53\right.$, p $<0.001$ ) (table 3). 
Table 3 Concentrations of soluble interleukin 2 receptor (sIL2R) in patients with active or inactive systemic lupus erythematosus with or without infection

\begin{tabular}{|c|c|c|c|c|c|}
\hline \multirow{2}{*}{$\begin{array}{l}\text { Serum } \\
\text { sILLR } \\
(U / m l)\end{array}$} & \multirow[t]{2}{*}{ Control } & \multicolumn{2}{|l|}{ Active disease } & \multicolumn{2}{|c|}{ Inactive disease } \\
\hline & & No infection & Infection & No infection & Infection \\
\hline $\begin{array}{l}0- \\
500- \\
1000- \\
1500- \\
>2000\end{array}$ & $\begin{array}{r}23 \\
0 \\
0 \\
0 \\
0\end{array}$ & $\begin{array}{r}12 \\
31 \\
5 \\
0 \\
2\end{array}$ & $\begin{array}{l}0 \\
4 \\
4 \\
4 \\
4\end{array}$ & $\begin{array}{r}41 \\
9 \\
- \\
-\end{array}$ & $\begin{array}{l}\overline{2} \\
1 \\
2 \\
3\end{array}$ \\
\hline Total & 23 & 50 & 16 & 50 & 8 \\
\hline
\end{tabular}

\section{Discussion}

Interleukin 2 receptor is one of the molecules expressed on the surface membrane when lymphocytes are activated. ${ }^{17} 18$ Part of the molecule is released into the circulation in a soluble form and this sIL2R reflects the degree of lymphocyte activation overall. In SLE the expression of IL2R on activated lymphocytes has been reported to be increased or decreased, ${ }^{19}$ and Wigfall et al suggested that IL2R expression on lymphocytes may correlate with disease activity. ${ }^{1820}$ Increased concentrations of sIL2R have been reported in patients receiving haemodialysis ${ }^{21}$ and in those with lymphomas $^{13} 1422$ and autoimmune disease. ${ }^{8-11} 23$ In SLE it had been shown that the concentration of sIL2R may be a marker of disease activity. ${ }^{910}$ Our study confirms this: patients with SLE had an increased concentration of sIL2R even when the disease seemed inactive (fig 1), suggesting that lymphocyte activation may still be present even though the disease is considered inactive by clinical criteria, but the concentration of sIL2R was much higher in active SLE. The sIL2R concentration was less than 500 units $/ \mathrm{ml}$ in all controls, $41 / 50(82 \%)$ patients with inactive SLE, and 12/50 (24\%) with active SLE (table 3).

When sIL2R was first described it was hoped that it might prove to be a sensitive marker of disease activity or early clinical relapse in SLE. Our serial study of 27 patients showed that in all but one patient the sILR2 concentration fell with control of the active disease (fig 2), and from the sIL2R concentration we could, to some extent, distinguish active from inactive disease. When disease activity was divided into three subgroups, however: mild, moderate, severe, sIL2R concentrations did not correlate with the activity of the disease (table 2), so sIL2R cannot be used to differentiate the grades of severity. We previously reported that $\beta_{2}$ microglobulin can be a useful test in this respect, ${ }^{24}$ but it was not sensitive enough to detect early serological relapse (unpublished observation). The sIL2R concentration may help to determine whether the disease is under adequate control by the current steroid and immunosuppressive treatment. Another prospective study is in progress in which sIL2R is measured serially in all patients with serological or early clinical relapse. We hope to see whether sIL2R is a useful predictor of relapse.

In patients with SLE both disease activity and infection can cause fever. It has been reported that CRP can distinguish between these causes. ${ }^{25}$ It is not a completely reliable marker, however, as the CRP fails to rise in some cases of severe infection and, on the other hand, many rise to a level indicative of infection in the presence of active disease alone (unpublished observations). The concentration of sIL2R in active SLE accompanied by infection is well above $1000 \mathrm{U} / \mathrm{ml}$ (especially for those with tuberculosis or fungal disease), whereas in those with active disease with no infection the concentration of sIL2R is only around 1000 $\mathrm{U} / \mathrm{ml}$. Similarly, patients with inactive SLE have a low concentration of SIL2R, whereas in the presence of infection the concentration soars markedly. Thus chronic infection is associated with a much raised SIL2R in both active and inactive SLE (table 3).

A comparison of the causes of infection showed that chronic infection (tuberculosis of fungal infections) was associated with a much higher concentration of SIL2R than other infections, such as pyogenic or herpes zoster infection $(p<0 \cdot 000)$. A further study of patients with tuberculosis who are not receiving immunosuppressive treatment is under way. It has been found that patients with active tuberculosis have raised SIL2R, which falls with treatment and sputum conversion, but in two patients with refractory tuberculosis their sIL2R concentrations remain markedly raised (unpublished observations). These results support the findings of this study and show that sIL2R concentration can help to distinguish chronic infections from other infections - an important distinction because tuberculous or fungal infection are important causes of morbidity in patients with SLE and may be associated with substantial mortality if treatment is delayed. A limitation of our study is the small number of patients with inactive SLE and infection, but most patients with inactive SLE are receiving minimal steroid or immunosuppressive treatment and development of serious infection is fairly unusual. Most patients with inactive SLE have an sIL2R concentration $\leq 500$ units $/ \mathrm{ml}$ (table 3 ) and therefore, an sIL2R concentration $>1500$ units $/ \mathrm{ml}$ strongly suggests the presence of infection $\left(\chi^{2}=49 \cdot 53, p<0 \cdot 001\right)$. A detailed search for infection is mandatory, especially for tuberculosis and fungus.

The authors would like to thank Ms T Tong for the excellen secretarial assistance and the medical illustration unit, faculty of medicine for their graphics and prints.

I Shoenfeld Y, Schuratz R S. Immunologic and genetic factors in autoimmune diseases. $N$ Engl f Med 1984; 311: 1019-29.

2 Abe T, Homura M. Immunological reactivity in patients with systemic lupus erythematosus: hormonal antibody syst cellur immune Scandinavica 1971; 17: 35-41.

3 Morimoto C, Reinherz E L, Schlossman S F, Schur P H, Mills J A, Steinberg A D. Alternations in immunoregulatory $T$ cell subsets in active systemic lupus erythematosus. $\mathcal{J}$ $T$ cell subsets in active syste

4 Linher-Israeli-M, Bakka A C, Kitridon R C, Gendler S, Gillis S, Horwitz D A. Defective production of interleukin 1 and interleukin 2 in patients with systemic lupus erythematosus. interleukin 2 in patients with syst

5 Balow J E, Tsoko G C. T and B lymphocytic function in patients with lupus nephritis: correlation with renal pathology. Clin Nephrol 1984; 21: 93-7.

6 Rubin L A, Kurman C C, Fritz M E, et al. Soluble interleukin 2 receptors are released from activated human lymphoid cell in vitro. $\mathcal{f}$ Immunol 1985; 135: 3172-7. 
7 Osawa H, Josimovic-Alasevic O, Diamatstein T. Interleukin 2 receptors are released by cells in vitro and in vivo. I. detection of soluble IL2 receptors in cell culture supernatants and in the serum of mice by immunoradiometric assay. Eur F Immunol 1986; 16: 467-9.

8 Semenzato G Bambara L M, Biasis D, et al. Increased serum levels of soluble interleukin-2 receptor in patients with levels of soluble interleukin-2 receptor in patients with systemic lupus erythematosus and

9 Wolf $R$ E, Brelsford $W$ G. Soluble interleukin-2 receptors in systemic lupus erythematosus. Arthritis Rheum 1988; 31 729-35.

10 Campen D H, Horwitz D A, Quismorio F P Jr, Ehresman G R, Martin W J. Serum levels of interleukin-2 receptor and activity of rheumatic diseases characterized by immune system activation. Arthritis Rheum 1988; 31: 1358-64.

11 Keystone E C, Snow K M, Bombradier C, Chang C H Nelson D L, Rubin L A. Elevated soluble interleukin-2 receptor levels in the sera and synovial fluids of patients with rheumatoid arthritis. Arthritis Rhewm 1988; 31: 844-9.

12 Stolc V, Krause J R. Interleukin-2 receptor levels are increased in blood of heart transplant patients during increased in blood of heart transplant patients during
infections. Diagnostic Clinical Immunology 1987; 5: 171-4.

13 Wagner D K, Kiwanka J, Edwards B K, Rubin L A, Nelson D L, Magrath I T. Soluble interleukin-2 receptor levels in patients with undifferentiated and lymphoblastic lymphomas: correlation with survival. F Clin Oncol 1987; 5: 1262-74.

14 Harrington D S, Patel I C, Lai P K, et al. Soluble interleukin2 receptors in patients with malignant lymphoma. Arch Pathol Lab Med 1988; 112: 597-601.

15 Tan E M, Cohen A S, Fries J F, et al. The 1982 revised criteria for the classification of systemic lupus erythematosus. Arthritis Rhewam 1982; 25: 1271-7.

16 Lockshin M D, Reinitz E D, Ruzin M L, Murrman M, Estes D. Lupus pregnancy, case control prospective study demonstrating absence of lupus exacerbation during or after pregnancy. Am F Med 1984; 77: 893-8.

17 Santoro T J, Malek T R, Rosenberg Y J, Morse H C Steinberg A D. Signals required for activation and growth of autoimmune T lymphocytes. $\mathcal{f}$ Mol Cell Immunol 1984; of autoimm $347-56$

18 Wigfall D R, Sakai R S, Wallace D J, Jordan S C. Interleukin-2 receptor expression in peripheral blood lymphocytes from systemic lupus erythematosus patients relationship to clinical activity. Clin Immunol Immunopathol 1988; 47: 354-62.

19 Ishida H, Kumagai S, Umehara H, et al. Impaired expression of high affinity interleukin 2 receptor on activated lymphocytes from patients with systemic lupus erythematosus. f Immunol 1987; 139: 1070-4.

20 Lakhanpal S, Handwerger B S. Interleukin 2 receptors and responsiveness to recombinant human interleukin 2 in patients with systemic lupus erythematosus. Mayo Clin Proc 1987; 62: 3-7.

21 Peacocke M, McLaughlin MI, Levey A, Pukin L A, Nilson D L. Elevated score levels of interleukin 2 receptor are p L. Elevated score levels of interleukin 2 receptor are present in patients maintained on

22 Mackeen L, Brown M, Ip S $\mathbf{H}$, et al. Serum interleukin 2 receptor as a marker for active $\mathrm{T}$ cell malignancy [Abstract]. Fed Proc 1986; 45: 454

23 Balderas R S, Josimovic-Alasevic O, Diamantstein T, Dixon F J, Theofilopoulos A N. Elevated titers of cell-free interleukin 2 receptor in serum of lupus mice. 7 Immunol 1987; 139: 1496-500.

24 Yeung $C K$, Wong $K \mathrm{~L}$, Wong $W \mathrm{~S}$, Chan $\mathrm{K} \mathrm{H}$. $\beta_{2}$ Microglobulin and systemic lupus erythematosus. f Rhewmatol 1986; 13: 1053-8.

25 Bravo M G, Alarcon-Segovia D. C-reactive protein in the differential diagnosis between infection and disease reactivation in SLE. $\mathcal{J}$ Rheumatol $1981 ; 8: 291-4$. 